\title{
Physical integrity of endive and chicory seeds determined by automated analysis of radiographic images
}

\author{
Marina Guimarães Brum de Castro ${ }^{1} \oplus$, André Dantas de Medeiros ${ }^{1}{ }^{\circ}$, \\ José Maria da Silva ${ }^{1 *} \mathbb{B}$, Laércio Junio da Silva ${ }^{1} \mathbb{B}$ \\ 1 Universidade Federal de Viçosa, Viçosa, MG, Brasil. E-mail: mari.castro08@gmail.com; andre.d.medeiros@ufv.br; jose.m.maria@ufv.br; laercio.silva@ufv.br
}

ABSTRACT: Seeds are commercialized in Brazil after rigorous quality control, which is performed by mandatory tests that are time consuming and frequently destructive. X-ray image analysis has been highlighted as it has the advantage of being fast, nondestructive, can be automated, and for some species, has high correlation with the physiological quality of the seeds. This study aimed to investigate the efficiency of the $X$-ray test, combined with digital image processing techniques, to evaluate the characteristics of the internal structures of endive (Cichorium endivia L.) and chicory (Cichorium intybus L.) seeds, as well as to relate these characteristics to the physical integrity and physiological potential of the seeds. Four commercial chicory seed lots and six commercial endive seed lots were submitted to the X-ray test and subsequent germination test. By visual analysis of the images, cracks, embryo malformation, and empty spaces in the seeds were identified. The seeds presented high physiological quality, which agrees with the data obtained in the radiographic image analysis. The physical parameters evaluated through image analysis inferred the seed integrity and seed filling. Although a low correlation between physical and physiological parameters was observed, the analysis of the radiographic images allowed the identification of seeds with low physical and physiological quality. Thus, X-ray analysis is efficient in evaluating the physical integrity of chicory and endive seeds and has the potential to infer their physiological quality.

\section{Integridade física de sementes de almeirão e chicória determinada por análise automatizada de imagens radiográficas}

RESUMO: A comercialização de sementes no Brasil é realizada após rigorosa verificação da qualidade de lotes por testes obrigatórios, que são demorados e a maioria de caráter destrutivo. A análise de imagens de raios $\mathrm{X}$ tem sido destacada devido a rapidez, por ser automatizada e não destrutiva, e para algumas espécies há alta correlação com a qualidade fisiológica das sementes. $O$ objetivo neste trabalho foi investigar a eficiência do teste de raios $X$, combinado com técnicas de processamento digital de imagens, para avaliar as estruturas internas de sementes de almeirão (Cichorium endivia L.) e chicória (Cichorium intybus L.), assim como relacionar estas características com a integridade física e o potencial fisiológico das sementes. Quatro lotes comerciais de sementes de almeirão e seis lotes comerciais de chicória foram submetidos ao teste de raios $X$ e subsequente teste de germinação. Pela análise visual das imagens foram identificadas trincas, malformação embrionária e espaços vazios nas sementes. A qualidade fisiológica das sementes foi alta, o que está de acordo com os dados obtidos na análise de imagens radiográficas. As características físicas avaliadas por meio da análise de imagens permitiram inferir sobre a integridade e o enchimento das sementes, de forma que apesar da baixa correlação entre as características físicas e fisiológicas, a análise das imagens radiográficas permitiu identificar sementes com baixa qualidade considerando estes dois atributos de qualidade. Assim, a análise de raios X é eficiente na avaliação da integridade física de sementes de almeirão e chicória e tem potencial para inferir sobre a qualidade fisiológica delas.

\section{Palavras-chave: Cichorium endivia L.; Cichorium intybus L.; qualidade de sementes; olerícolas; raios X}

\footnotetext{
* Jose Maria da Silva - E-mail: jose.m.maria@ufv.br (Corresponding author)

Associate Editor: Edna Ursulino Alves
} 


\section{Introduction}

Endive (Cichorium endivia L.) and chicory (Cichorium intybus L.) are perennial vegetables belonging to the Asteraceae family. Both are sources of vitamins A, B, C, and $D$, and they have diuretic, laxative, and antioxidant qualities, making them interesting for medicinal purposes (Al-Snafi, 2016). Due to their bitter taste and the need for mild climates for successful cultivation, they are rarely consumed in the Brazilian market.

These two species are sexually propagated, and the seeds are used to produce seedlings that are transplanted into the field. Thus, the seeds must have good physiological quality to guarantee an adequate stand in the field, with seedlings of greater vigor.

Seed quality is assessed in accredited laboratories before the commercialization of the lots. Currently, the mandatory tests are physical purity analysis, analysis of the presence of other seeds, and germination tests (Brasil, 2009). Despite not being mandatory, vigor tests are used by seed companies in their quality control programs. However, the seed industry has been looking for faster and more efficient tests to support internal quality control in decision making regarding the disposal of low-quality seed lots, which can save time and resources.

An imaging technology that has been helping analyze seed quality is the X-ray. In addition to being a fast method, several studies have shown a high correlation between the parameters obtained with image analysis and the physical and physiological quality of seeds (Abud et al., 2010; Medeiros et al., 2018). The easy visualization of cracks and internal lesions on radiographs can also help in the identification and search for solutions to failures in harvesting and post-harvest processes.

$X$-ray imaging is based on the absorption capacity of these rays by the tissues of the seed. A lighter color in the radiograph corresponds to denser tissues, which blocks the passage of the X-rays, and darker areas correspond to less dense tissues, which permits the passage of the rays (Simak, 1991). As lowintensity rays are used in the X-ray test for seed analysis, the physiological quality of the seeds is not compromised, allowing their use in other tests or for sowing (Xia et al., 2019).

Thus, the objective of this work was to investigate the efficiency of the X-ray test, combined with digital image processing techniques, to evaluate characteristics of the internal structures of endive and chicory seeds, as well as to relate these characteristics to the physical integrity and physiological potential of the seeds.

\section{Materials and Methods}

\section{Study location and plant material}

The research was conducted at the Seed Research Laboratory of the Department of Agronomy and X-ray Laboratory of the Department of Entomology at the Federal University of Viçosa, Minas Gerais, Brazil. Four commercial seed lots of an endive cultivar and six commercial seed lots of a chicory cultivar were used.

\section{Radiographic image acquisition}

One hundred seeds from each lot were divided into four replications of 25 seeds and distributed in $9 \mathrm{~cm}^{2}$ of adhesive plastic. This procedure was necessary to maintain the position of the seed, making its individual evaluation in subsequent analyses possible.

After being glued on the adhesive plastic, the seeds were submitted to the X-ray test, using a Faxitron MX-20 to generate the digital radiographs. The lots were exposed to radiation for 19 seconds at $23 \mathrm{kV}$, at a distance of $20.9 \mathrm{~cm}$, and the image contrast was calibrated at 2682 (center) x 9280 (width). The adjustment of the voltage and the time of exposure of the seeds to radiation was chosen based on preliminary tests with seeds of both species.

\section{Computerized image processing and visual analysis}

Digital radiographs were analyzed automatically using Image ${ }^{\circledR}$ software, in which the PhenoXray macro (Medeiros et al., 2020a) was adapted for the seeds of the species evaluated in the present study. The macro initially converted the images to 8 bits and calibrated the scale, converting pixels to millimeters ( 80 pixels $=1 \mathrm{~mm}$ ). Then, the background of the image was removed, and the image was duplicated and segmented using Yen's thresholding algorithm (Yen et al., 1995). Finally, particle analysis was performed, redirecting the mask created to the original image, generating seven variables. The results were automatically saved in a TXT file, and an image file was generated with the identified seeds.

Multiple variables were evaluated using the automatic analysis of the digital radiographs. Area $(A)$ corresponded to the space occupied by the seed in the image in pixels squared; this value was then converted by the macro to millimeters squared $\left(\mathrm{mm}^{2}\right)$. Perimeter $(P)$ corresponded to the length in millimeters of the external limit of the seed in the radiograph. Circularity $(\mathrm{C})$, which ranged from 0 to 1 , was obtained using Equation 1. The more circular the seed, the greater the $C$ value.

$$
\mathrm{C}=4 \pi \times \frac{\text { area }}{\text { perimeter }^{2}}
$$

Relative density (RelDens) was obtained using Equation 2.

RelDens $=\frac{\sum \text { gray value of the seed pixels }}{\text { number of pixels that occupies the seed area }}$

The integrated density (IntegDens) was obtained using Equation 3.

IntegDens $=\frac{\sum \text { gray value of the seed pixels }}{\text { number of pixels that occupies the seed area }} \times$ area 
Asymmetry was obtained by the degree of deviation or deviation from the symmetry of the pixel values distribution. Seed filling was calculated by the percentage of seed area on the radiograph corresponding to pixels with values above 5 , in grayscale ranging from 0 to 225 .

In addition to computerized processing, visual analysis of radiographs was performed. The number of seeds with physical damage and malformation of the endosperm were registered.

\section{Physiological analysis}

After the X-ray test, the same seeds, arranged following the same order used in the X-ray test, were submitted to physiological quality assessment through the germination test. For this, the seeds were distributed in acrylic boxes on two germination papers (Germitest) previously moistened with distilled water in the proportion of 2.5 times the weight of the dry paper. The seeds were kept under alternating temperature conditions $\left(20-30{ }^{\circ} \mathrm{C}\right)$ for 14 days (Brasil, 2009). Daily counts of the number of seeds showing radicle protrusion (radicle length greater than $2 \mathrm{~mm}$ ) and germinated seeds (normal seedlings) were performed (Brasil, 2009). Through this data, the percentage of germinated seeds, percentage of seeds with radicle protrusion, the germination speed index (GSI), and the average time for germination of $50 \%$ of the seeds (T50) were calculated using the SeedCalc package (Silva et al., 2019).

GSI was calculated by Equation 4, where $n$ is the number of germinated seeds on each day of the daily count until the last count, and $t$ is the number of days after the start of the test in each count.

$$
\mathrm{GSI}=\sum \mathrm{k}_{\mathrm{i}}=\frac{\mathrm{n}_{\mathrm{i}}}{\mathrm{t}_{\mathrm{i}}}
$$

The T50 was calculated using Equation 5 , where $n$ is the final number of germinated seeds, $n_{i}$ and $n_{j}$ are the numbers of germinated seeds at times $t_{i}$ and $t_{j}$, respectively.

$$
\mathrm{T} 50=\frac{\mathrm{t}_{\mathrm{i}}+\left\{\left[\frac{\mathrm{N}}{2}\right]-\mathrm{n}_{\mathrm{i}}\right\} \times\left(\mathrm{t}_{\mathrm{j}}-\mathrm{t}_{\mathrm{i}}\right)}{\left(\mathrm{n}_{\mathrm{j}}-\mathrm{n}_{\mathrm{i}}\right)}
$$

At the end of the germination test, images of the seedlings were obtained, and the seedling length was measured using Image ${ }^{\circledR}$ software. The growth, uniformity, and vigor indices were calculated using the SeedCalc package (Silva et al., 2019).

The uniformity index (Unif) was calculated using Equation 6 , where $X_{i}$ is the analyzed seedling size, $\bar{x}$ is the average seedling size, $n$ is the total number of evaluated seedlings, and $n_{\text {dead }}$ is the number of non-germinated seeds or dead seedlings.

$$
\text { Unif }=\left[1-\frac{\sum_{\mathrm{i}=1}^{\mathrm{n}}\left|\mathrm{X}_{\mathrm{i}}-\overline{\mathrm{x}}\right|}{\mathrm{n} \times \mathrm{X}}\right] \times 1000-\left[\mathrm{n}_{\mathrm{dead}} \times\left(\frac{50}{\mathrm{n}}\right)\right]
$$

The experimental growth index was calculated using Equation 7, in which the mean $\mathrm{CT}$ is the average of the total seedling length of the repetition and $\mathrm{Xmax}$ is the average of the total length of $5 \%$ of the largest seedlings in the experiment:

$$
\text { Growth }=\left(\frac{\text { meanCT }}{\mathrm{X} \max }\right) \times 1000
$$

The vigor index was obtained using Equation 8, with adjustable coefficients for growth (wg) and uniformity (wu).

$$
\text { Vigor }=(\text { Growth } \times w g)+(\text { Unif } \times w u)
$$

\section{Statistical analyses}

The data obtained by the PhenoXray macro (physical parameters) and the SeedCalc package (physiological parameters) were subjected to analysis of variance (ANOVA). The averages obtained were compared by Tukey's test ( $p \leq 0.05)$, except for the visual analysis that was performed descriptively. Pearson's correlation coefficient ( $r$ ) was calculated between all physical and physiological variables of the seeds (t-test, $p \leq 0.05)$. R software (R Core Team, 2019) was used for statistical analyses.

\section{Results and Discussion}

\section{Structural analysis of seeds with X-ray imaging}

The seed moisture content was 8.9 and $8.3 \%$ for the endive and chicory seeds, respectively. A high seed water content can affect the quality of the radiographs, but a low level of water was present in the evaluated seeds. Association with the configurations of X-ray equipment allowed us to obtain radiographs with good resolution and adequate detail of the internal structures of the seeds (Figure 1 ).

Through the X-ray images, it was possible to visualize the boundaries of the integument and the embryo in both species. Some defects, such as malformation of the endosperm and

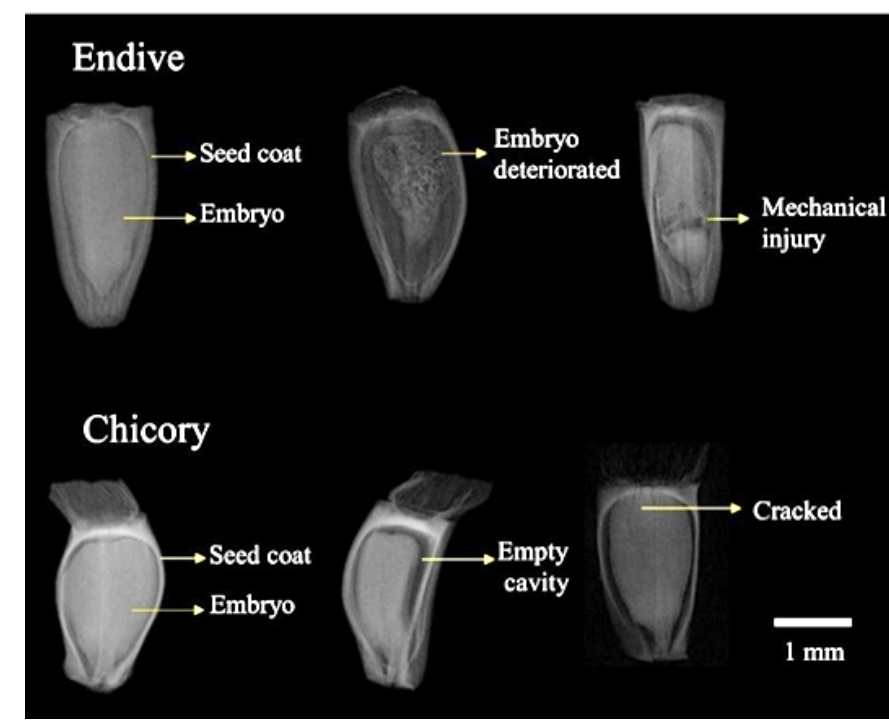

Figure 1. Radiographic images of endive and chicory seeds. 
mechanical damage characterized by cracks in some endive seeds, were also observed. However, chicory seeds did not present a malformation of the endosperm, but damage and larger empty spaces between the embryo and integument were identified in some seeds. In studies with pepper (Medeiros et al., 2020a), Brachiaria (Medeiros et al., 2020b), oil moringa (Noronha et al., 2018), sweet pepper (Gagliardi \& Marcos-Filho, 2011), and pumpkin (Marcos-Filho et al., 2010), strong relationships between empty space and seed quality were observed, in which lower levels of seed filling reflected less vigorous seeds. Therefore, part of the seeds may have had a compromised physiological quality. Despite the easy identification of mechanical damage, malformation of the endosperm, and empty spaces, it was not possible to distinguish the internal structures of the seed embryo in the two species (Figure 1).

Through visual analysis of the radiographs (Table 1), a low number of malformed and damaged endive seeds were identified, and there was no significant variation between seed lots. The same could be observed for the number of chicory seeds with mechanical damage. These results were related to the high uniformity of the seeds since commercial seed lots were used in this study.

From the parameters obtained with the automatic analysis of the images (Table 1), the area of the endive seeds from lot 2 was statistically superior to the seeds from lot 1 . The seed perimeter of lot 3 was higher than the seeds of lots 1 and 4, which did not differ significantly from each other. The seeds of the different lots did not differ significantly for circularity, relative density, integrated density, asymmetry, and seed filling.

In both species, the seeds from different seed lots had different areas and perimeters. This information is important since some studies correlated these variables and the circularity with seed maturation and the environment where the seeds were produced (Abud et al., 2018; Javorski et al., 2018; Lafond \& Baker, 1986; Medeiros et al., 2018). Thus, well-formed seeds had greater values for these parameters. Additionally, these variables can assist in the identification and classification of seeds with desirable shape characteristics for sowing.

The information on relative and integrated density was strictly linked to the density of the analyzed tissue. The denser tissues had higher gray levels than the less dense tissues. According to Medeiros et al. (2018), these variables assisted in the identification of malformed or less filled seeds, since they had lower gray levels. To determine if the density and the other variables could infer the physiological quality of the seeds, a germination test was performed.

\section{Physiological analysis of seeds}

Through the physiological characteristics evaluated, the endive and chicory seed lots were found to be of high quality. For the T50 index, only endive seed lots 1 and 4 were statistically different. In the physiological analysis of chicory seeds, significant variation was observed for the germination speed index, T50, and uniformity index. Lots 4 and 6 had greater values for GSI and lower values for T50, compared to the other lots. For seedling uniformity, lot 6 was higher than lot 2 .

In the germination test, all the seed lots had more than $93 \%$ of seeds with radicle protrusion (greater than $2 \mathrm{~mm}$ ). As for the number of normal seedlings (percentage of germination), all lots analyzed exceeded the minimum percentage of $75 \%$ of germination, which is required for the commercialization of seeds of both species (Brasil, 2009). These data indicate that

Table 1. Average values for physical variables obtained through radiographic analysis of endive and chicory seeds.

\begin{tabular}{|c|c|c|c|c|c|c|c|c|c|c|}
\hline \multirow{3}{*}{$\begin{array}{l}\text { Seed } \\
\text { lot }\end{array}$} & \multicolumn{7}{|c|}{ Automatic analysis } & \multicolumn{3}{|c|}{ Visual analysis } \\
\hline & \multirow{2}{*}{$\begin{array}{c}A \\
\left(\mathrm{~mm}^{2}\right)\end{array}$} & \multirow{2}{*}{$\begin{array}{c}P \\
(\mathrm{~mm})\end{array}$} & \multirow[t]{2}{*}{ Circ } & \multirow{2}{*}{$\begin{array}{c}\text { RelDens } \\
\left(\text { (Gray pixel }^{-1} \text { ) }\right.\end{array}$} & \multirow{2}{*}{$\begin{array}{c}\text { IntDens } \\
\left(\text { Gray } \mathrm{mm}_{\text {pixel }}^{-1} \text { ) }\right.\end{array}$} & \multirow[t]{2}{*}{ Asymmetry } & $\begin{array}{l}\text { Seed } \\
\text { filling } \\
\end{array}$ & $\begin{array}{c}\text { Normal } \\
\text { seeds }\end{array}$ & $\begin{array}{c}\text { Damaged } \\
\text { seeds } \\
\end{array}$ & $\begin{array}{c}\text { Abnormal } \\
\text { seed }\end{array}$ \\
\hline & & & & & & & \multicolumn{4}{|c|}{ (\%) } \\
\hline 1 & $2.69 c$ & $10.5 \mathrm{~b}$ & 0.315 & 27.85 & 74.85 & -0.31 & 99.98 & 93 & 6 & 1 \\
\hline 2 & $2.84 \mathrm{a}$ & $10.92 a b$ & 0.305 & 27.20 & 77.29 & -0.27 & 99.97 & 97 & 3 & 0 \\
\hline Fc & $7.17^{*}$ & $5.65^{*}$ & $5.31^{\text {ns }}$ & $2.00 \mathrm{~ns}$ & $1.49^{\mathrm{ns}}$ & $2.02^{\text {ns }}$ & $3.14^{\mathrm{ns}}$ & - & - & - \\
\hline $\mathrm{CV}$ & 2.11 & 2.75 & 2.41 & 1.67 & 2.78 & 14.64 & 0.01 & - & - & - \\
\hline \multicolumn{11}{|c|}{ Chicory } \\
\hline 1 & $2.77 \mathrm{a}$ & $13.84 \mathrm{a}$ & $0.192 \mathrm{c}$ & $30.22 \mathrm{~d}$ & $83.46 a$ & $0.20 \mathrm{a}$ & 99.96 & 97 & 3 & 0 \\
\hline 2 & $2.47 \mathrm{c}$ & $11.92 \mathrm{bc}$ & $0.228 a b$ & $32.65 b$ & $80.40 a b$ & $0.14 a b$ & 99.97 & 95 & 5 & 0 \\
\hline $\mathrm{Fc}$ & $29.36^{*}$ & $17.58 *$ & $6.63^{*}$ & $42.55^{*}$ & $2.96 *$ & $14.21 *$ & $2.37^{\mathrm{ns}}$ & - & - & - \\
\hline $\mathrm{CV}$ & 2.05 & 3.61 & 6.50 & 1.40 & 2.71 & 111.95 & 0.01 & - & - & - \\
\hline
\end{tabular}

$*$, ns: significant and non-significant, respectively, by the $\mathrm{F}$ test $(\mathrm{p}=0.05)$. Different letters in the column represent significant differences between the seed lots by the Tukey test ( $\mathrm{p}<$ 0.05). $\mathrm{Fc}=\mathrm{F}$ calculated; $\mathrm{CV}=$ coefficient of variation. $\mathrm{A}=$ area; $\mathrm{P}=$ perimeter; Circ = circularity; RelDens = relative density; IntDens $=$ integrated density. 
Table 2. Average values obtained for the physiological parameters of endive and chicory seed lots.

\begin{tabular}{|c|c|c|c|c|c|c|c|c|}
\hline \multirow{2}{*}{ Seed lot } & Germination & Radicle protrusion & \multirow{2}{*}{$\begin{array}{c}\text { GSI } \\
\text { index }\end{array}$} & \multirow{2}{*}{$\begin{array}{c}\text { T50 } \\
\text { (days) }\end{array}$} & \multirow{2}{*}{$\begin{array}{l}\text { Seedling length } \\
(\mathrm{mm})\end{array}$} & \multirow{2}{*}{ Unif } & \multirow{2}{*}{ Growth } & \multirow{2}{*}{ Vigor } \\
\hline & & $\%$ & & & & & & \\
\hline \multicolumn{9}{|c|}{ Endive } \\
\hline 2 & 92 & 99 & 4.93 & $4.13 a b$ & 26.7 & 767 & 1190 & 1063 \\
\hline 3 & 92 & 97 & 4.85 & $4.08 a b$ & 27.2 & 811 & 1211 & 1091 \\
\hline 4 & 83 & 93 & 4.28 & $4.38 a$ & 25.2 & 751 & 1126 & 1013 \\
\hline \multicolumn{9}{|c|}{ Chicory } \\
\hline 1 & 96 & 97 & $4.52 b$ & $4.69 a b$ & 43.4 & $770 a b$ & 935 & 886 \\
\hline 2 & 97 & 98 & $4.40 \mathrm{~b}$ & $4.96 \mathrm{a}$ & 39.6 & 744 b & 852 & 820 \\
\hline 3 & 94 & 99 & $4.56 b$ & $4.69 a b$ & 47.9 & $787 \mathrm{ab}$ & 1032 & 959 \\
\hline 4 & 100 & 100 & $5.33 \mathrm{a}$ & $4.18 \mathrm{bc}$ & 49.7 & $808 a b$ & 1072 & 993 \\
\hline
\end{tabular}

$*$, ns: significant and non-significant, respectively, by the $\mathrm{F}$ test $(\mathrm{p}=0.05)$. Different letters in the column represent significant differences between the seed lots by the Tukey test ( $\mathrm{p}$ $<0.05$ ). Fc = F calculated; CV = coefficient of variation. GSI = germination speed index; T50 = time required for germination of $50 \%$ of the seeds; Unif $=$ uniformity index; Growth = experimental growth index; Vigor = vigor index.

the seeds used in the present work had high viability, as they originated from commercial seed lots.

The chicory and endive seed lots showed high physiological quality, differing only in the speed of germination and seedling uniformity, which are characteristics linked to seed vigor (FinchSavage \& Bassel, 2016). The significant differences for T50 in both species and GSI in chicory are important information since, according to Marcos-Filho (2015), the irregularity in the time of radicle protrusion and seed germination can result in delayed harvests or irregularities in plant development and growth.

Despite the high germination (above 83\%), nongerminated seeds and abnormal seedlings were observed in both species. The identification of these seeds using the X-ray technique can save time and resources for seed producer companies and improve internal quality control, mainly through the disposal of low-quality seed lots. Thus, it was important to correlate the parameters obtained with the physiological analysis (Table 2 ) and the analysis of the radiographic images (Table 1 ).

Relationship between internal morphology, physical integrity, and physiological quality

There was no significant correlation between most of the physical and physiological parameters analyzed in the present study (Figure 2). For the endive seeds, there was a positive correlation between area, integrated density, and asymmetry. A negative and significant correlation was observed between the perimeter and circularity. For chicory seeds, a significant correlation was identified between seed filling and root protrusion, indicating a possible association between these physical and physiological variables. The other positive correlations observed were between area and perimeter, area and integrated density, and area and asymmetry. A negative correlation between area and circularity, area and relative density, perimeter and circularity, and perimeter and relative density was observed.

According to Abud et al. (2018), the positive and significant correlation between seedling length and relative density in broccoli seeds demonstrated that the method of analysis by X-ray imaging was efficient for inferring the physiological quality of the seeds. In the present study, the low correlation observed between the physical and physiological characteristics (Figure 2 ) is probably due to the low variability of quality among the seed lots analyzed. Thus, the use of more distinct lots, with more contrasting levels of physiological quality in the two species, is indicated for more precise identification of these correlations.

However, a significant positive correlation was observed between seed filling and the percentage of radicle protrusion in chicory seeds, as well as a significant negative correlation between damage and radicle protrusion, and damage and GSI in endive seeds (Figure 2). These data are promising because, even though the seeds of lower quality were in a low proportion, it was still possible to identify the correlation between these variables. Thus, the X-ray technique, followed by automated analysis of endive and chicory seeds, is promising for identifying individual seeds and seed lots showing low physiological quality.

With the individual analysis of the radiographs and the seedlings after the germination test, some relationships were observed (Figure 3). The seeds previously evaluated as well-formed in the visual analysis of the radiographs generated mostly normal seedlings (Figures $3 a$ and $3 d$ ). In the occurrence of mild cracks in endive seeds, malformation of cotyledons and little root development were observed (Figure 3b). In a particular situation of chicory seed with lateral injury, malformation of one of the cotyledons was observed. In the case of more severe mechanical damage, as in the case of the seed in Figure 3c, the seed was not viable. 
ENDIVE
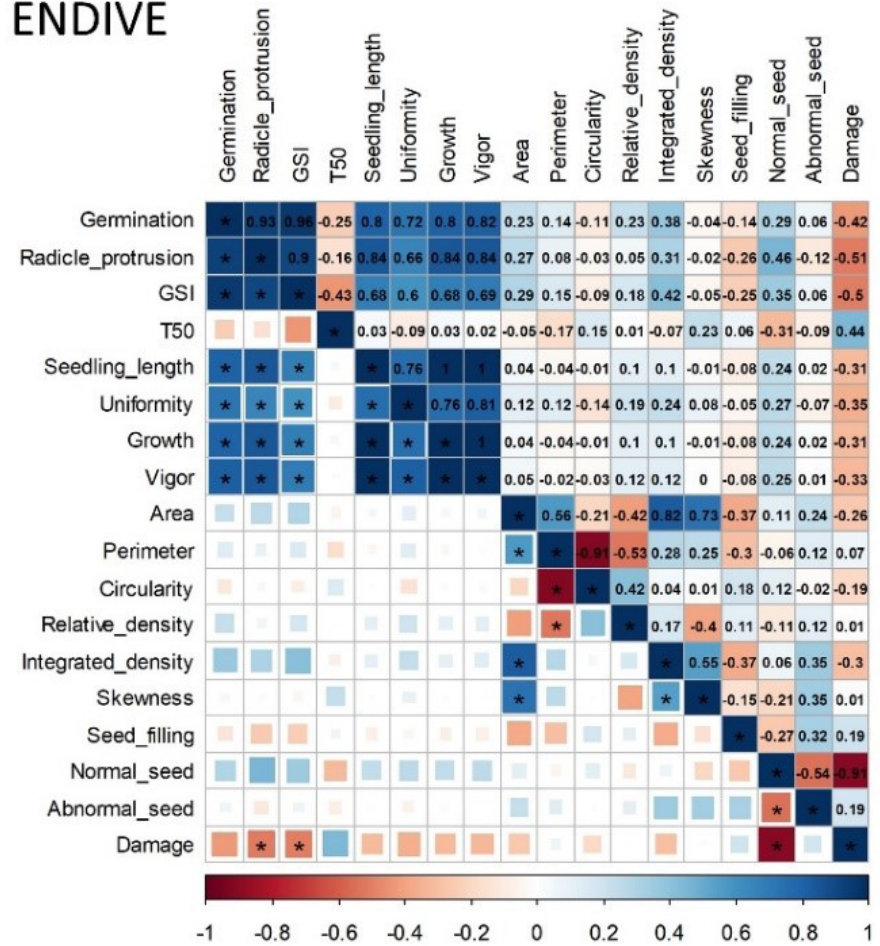

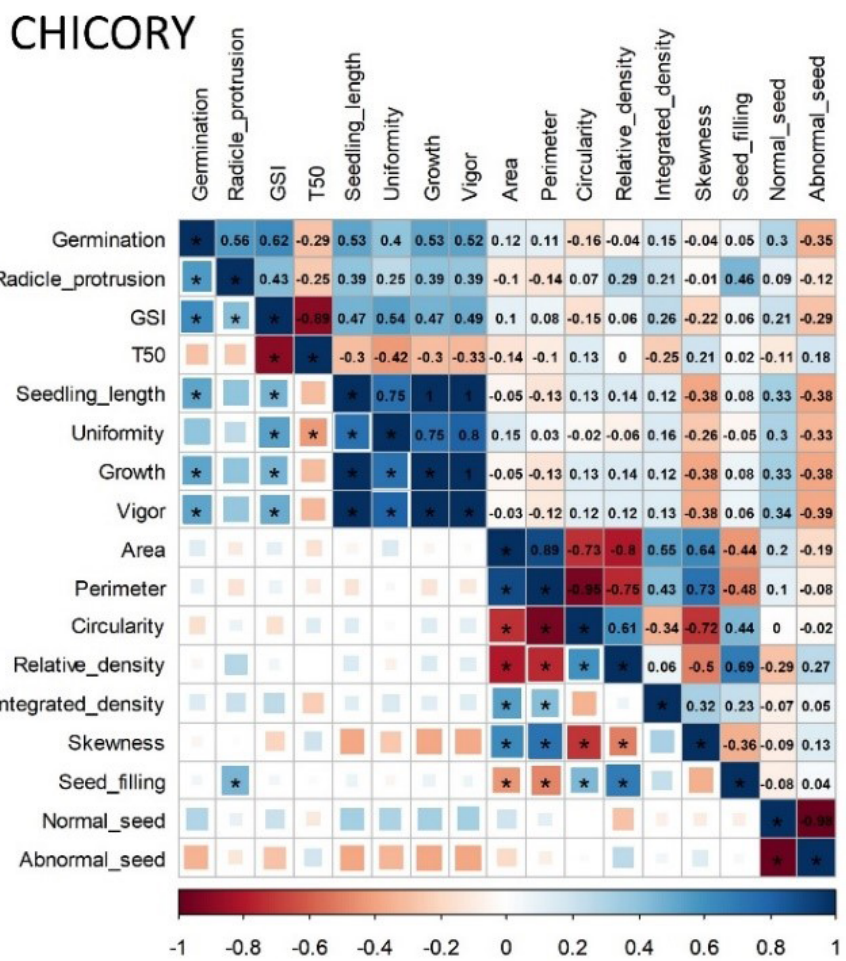

* - significant by t-test $(p<0.05)$. GSI = germination speed index; $T 50=$ time required for germination of $50 \%$ of the seeds.

Figure 2. Pearson correlation between physical and physiological parameters of endive and chicory seeds.

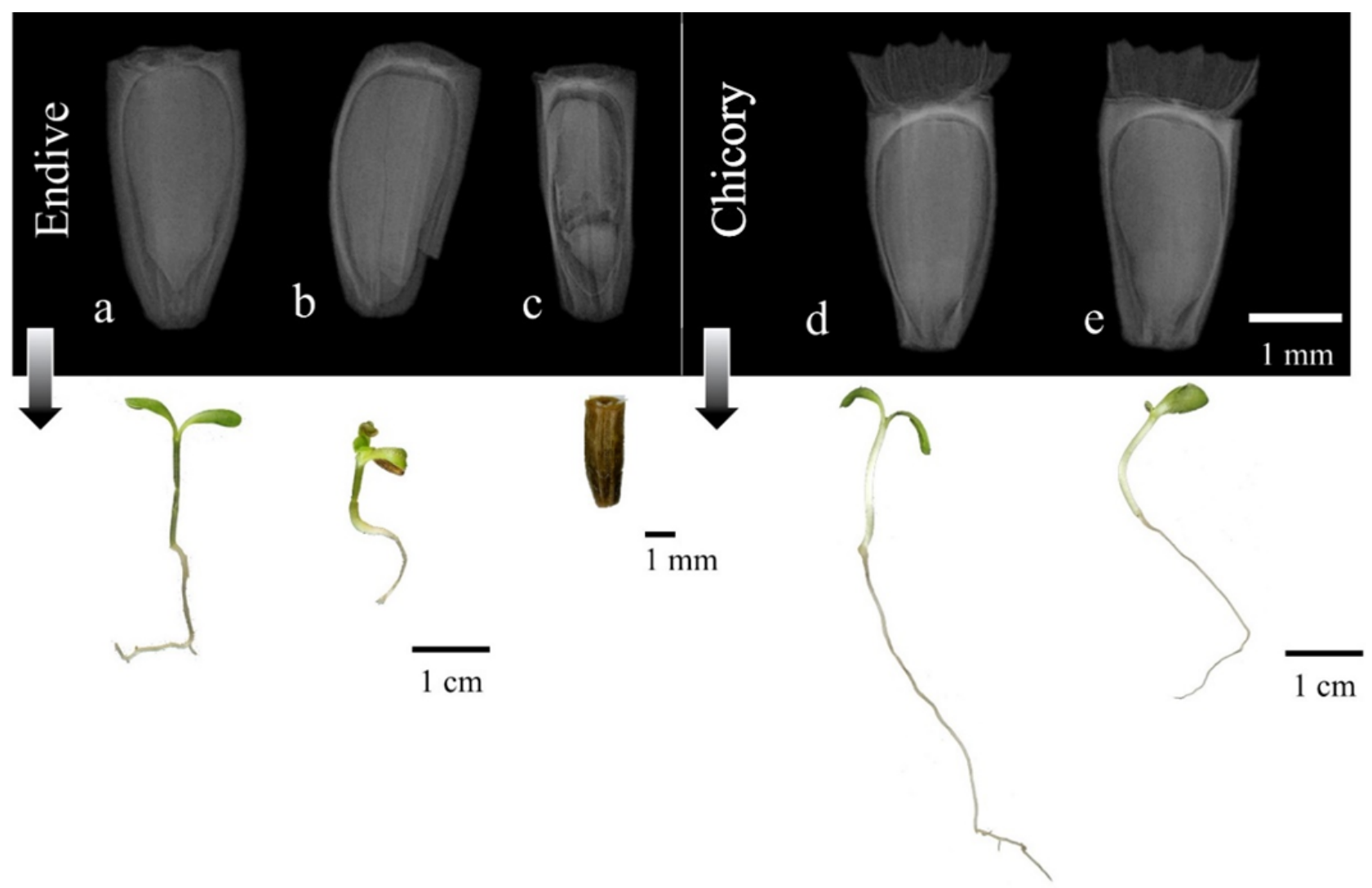

Figure 3. Individual relationship between radiographs of endive and chicory seeds and their respective seedlings. Seed without damage (a), seed with a slight crack (b), intense mechanical damage (c), well-formed (d), small lateral lesion (e).

The relationships observed in Figure 3 confirmed the great potential of the X-ray technique as a fast, nondestructive, and efficient methodology for assessing the physical quality of the seeds and for obtaining information about physiological quality. In this study, the X-ray technique offered important information about the seeds, identifying possible causes of the low quality 
of seed lots. However, further studies are recommended with lots presenting seeds with greater differences in physiological quality. Thus, the relationship between the physical parameters, obtained with the automatic analysis of radiographs, and the germination and vigor data of the endive and chicory seeds could be more evident.

\section{Conclusion}

X-ray analysis followed by the automatic processing of the radiographs was efficient for the evaluation of the physical integrity of endive and chicory seeds. The variables obtained have the potential to infer the physiological quality of the seeds of both species rapidly and nondestructively.

\section{Compliance with Ethical Standards}

Author contributions: Conceptualization: MGBC, LJS; Data curation: MGBC, ADM; Formal analysis: ADM, JMS; Funding acquisition: LJS; Investigation: MGBC; Methodology: MGBC; Project administration: LJS; Resources: LJS; Supervision: LJS; Validation: MGBC, ADM, JMS, LJS; Visualization: MGBC, ADM, JMS, LJS; Writing - original draft: MGBC, ADM, JMS; Writing review \& editing: MGBC, ADM, JMS, LJS.

Conflict of interest: The authors declare no conflict of interest.

Financing source: Coordenação de Aperfeiçoamento de Pessoal de Nível Superior, Brasil (CAPES), Finance Code 001.

\section{Literature Cited}

Abud, H. F.; Cicero, S. M.; Gomes Junior, F. G. Radiographic images and relationship of the internal morphology and physiological potential of broccoli seeds. Acta Scientiarum. Agronomy, v. 40, n. 1, p. 1-9, 2018. https://doi.org/10.4025/actasciagron.v40i1.34950.

Abud, H. F.; Gonçalves, N. R.; Reis, R. G. E.; Gallão, M. I.; e Innecco, R. Morphology of seed and seedling of safflower. Revista Ciência Agronômica, v. 41, n. 2, p. 259-265, 2010. https://doi. org/10.1590/S1806-66902010000200013.

Al-Snafi, A. E. Medical importance of Cichorium intybus - A review. IOSR Journal of Pharmacy, v. 6, n.3, p. 41-56, 2016. http://www. iosrphr.org/papers/v6i3/E0634156.pdf. 06 Sep. 2020.

Brasil. Ministério da Agricultura, Pecuária e Abastecimento. Regras para análise de sementes. Brasília: MAPA; ACS, 2009. 399 p.

Finch-Savage, W. E.; Bassel, G. W. Seed vigour and crop establishment: extending performance beyond adaptation. Journal of Experimental Botany, v. 67, n. 3, p. 567-591, 2016. https://doi. org/10.1093/jxb/erv490.

Gagliardi, B.; Marcos-Filho, J. Relationship between germination and bell pepper seed structure assessed by the X-ray test. Scientia Agricola, v. 68, n. 4, p. 411-416, 2011. https://doi.org/10.1590/ S0103-90162011000400004.
Javorski, M.; Castan, D. O. C.; Silva, S. S.; Gomes-Junior, F. G.; Cicero, S. M. Image analysis to evaluate the physiological potential and morphology of pearl millet seeds. Journal of Seed Science, v. 40, n.2, p. 127-134, 2018. https://doi.org/10.1590/2317$1545 v 40 n 2176904$.

Lafond, G. P.; Baker, R. J. Effects of genotype and seed size on speed of emergence and seedling vigor in nine spring wheat cultivars. Crop Science, v. 26, n.2, p. 341-346, 1986. https://doi.org/10.2135/cro psci1986.0011183X002600020027x.

Marcos-Filho, J. Seed vigor testing: an overview of the past, present and future perspective. Scientia Agricola, v. 72, n. 4, p. 363-374, 2015. https://doi.org/10.1590/0103-9016-2015-0007.

Marcos-Filho, J.; Gomes Junior, F. G.; Bennett, M. A; Wells, A. A; Stieve, S. Using Tomato Analyzer software to determine embryo size in x-rayed seeds. Revista Brasileira de Sementes, v. 32, n. 2, p. 146153, 2010. https://doi.org/10.1590/S0101-31222010000200018.

Medeiros, A. D.; Araújo, J. O.; Zavala-León, M. J.; Silva, L. J.; Dias, D. C. F. S. Parameters based on $\mathrm{x}$-ray images to assess the physical and physiological quality of Leucaena leucocephala seeds. Ciência e Agrotecnologia, v. 42, n. 6, p. 643-652, 2018. https://doi. org/10.1590/1413-70542018426023318

Medeiros, A. D.; Silva, L. J.; Pereira, M. D.; Oliveira, A. M. S.; Dias, D. C. F. S. High-throughput phenotyping of brachiaria grass seeds using free access tool for analyzing X-ray images. Anais da Academia Brasileira de Ciencias, v. 92, suppl. 1, 2020b. https:// doi.org/10.1590/0001-3765202020190209.

Medeiros, A. D.; Zavala-León, M. J.; Silva, L. J.; Oliveira, A. M. S.; Dias, D. C. F. S. Relationship between internal morphology and physiological quality of pepper seeds during fruit maturation and storage. Agronomy Journal, v. 112, n. 1, p. 25-35, 2020a. https:// doi.org/10.1002/agj2.20071.

Noronha, B. G. de; Medeiros, A. D. de; Pereira, M. D. Avaliação da qualidade fisiológica de sementes de Moringa oleifera Lam. Ciência Florestal, v. 28, n. 1, p. 393-402, 2018. https://doi. org/10.5902/1980509831615.

R Core Team. R: a language and environment for statistical computing. Vienna: R Core Team, 2019. https://www.r-project.org/. 01 Jul. 2020.

Silva, L. J.; Medeiros, A. D. de; Oliveira, A. M. S. SeedCalc, a new automated $\mathrm{R}$ software tool for germination and seedling length data processing. Journal of Seed Science, v. 41, n.2, p. 250-257, 2019. https://doi.org/10.1590/2317-1545v42n2217267.

Simak, M. Testing of forest tree and shrub seeds by X-radiography. In: Gordon, A. G.; Gosling, P.; Wang, B. S. (Eds.). Tree and shrub seed handbook. 1.ed. Zurich: ISTA, 1991. p.1-28.

Xia, Y.; Xu, Y.; Li, J.; Zhang, C.; Fan, S. Recent advances in emerging techniques for non-destructive detection of seed viability: A review. Artificial Intelligence in Agriculture, v. 1, p. 35-47, 2019. https://doi.org/10.1016/j.aiia.2019.05.001.

Yen, J.; Chang, F.; Chang, S. A new criterion for automatic multilevel thresholding. IEEE Transactions on Image Processing, v. 4, n.3, p. 370-378, 1995. https://doi.org/10.1109/83.366472. 